\section{Organic Fertility Sources for the Production of Short-day Organic Onion Transplants}

\author{
George E. Boyhan ${ }^{1,3}$ and C. Randy Hill ${ }^{2}$
}

Additional Index wORDs. spring onions, nonstorage onions, Allium cepa, nutrients, sustainable, Vidalia onions

SuMMARY. This study evaluated poultry litter, commercial organic fertilizer, and compost for organic production of onion (Allium cepa) transplants within the Vidalia onion growing region of southeastern Georgia. Two field experiments were conducted. The first experiment tested six rates of poultry litter (0-10 tons) acre). The second experiment tested a factorial combination of two rates of nitrogen (N) $(0$ and $130 \mathrm{lb} /$ acre $)$ and three rates of compost $(0,5$, and 10 tons/acre). Seedling weight, length, and diameter were measured $\approx 10$ weeks after sowing. Poultry litter had a significant increasing linear effect on plant weight and diameter. There was also a significant increasing quadratic effect on plant length. Commercial organic fertilizer $(3 \mathrm{~N}-0.9 \mathrm{P}-2.5 \mathrm{~K})$ at $130 \mathrm{lb} /$ acre $\mathrm{N}$ had a significant effect on plant length, but compost at 0,5 , or 10 tons/acre did not affect plant length. There were organic fertilizer by compost interactions for plant weight and diameter. There was a significant effect on plant diameter with organic fertilizer $(130 \mathrm{lb} /$ acre $\mathrm{N})$ and 10 tons/acre compost, but there was no fertilizer effect on plant diameter at 0 or 5 tons/acre compost. The interaction effect on plant weight indicated there was a significant effect from fertilizer with 5 and 10 tons/acre compost, but not with 0 tons/acre. Based on this study, nutrition should not be a problem in producing organic onion transplants in southeastern Georgia. Four to 6 tons/acre fresh poultry litter should be adequate for producing good quality transplants. An alternative approach of using organic fertilizer at a rate of $130 \mathrm{lb} /$ acre $\mathrm{N}$ with 5 to 10 tons/acre compost can also be used to produce good quality transplants.

$\mathrm{T}$ he value of Georgia's onion crop is estimated at over $\$ 125$ million (Boatright and McKissick, 2006). This success is because of the branded Vidalia ${ }^{\circledR}$ name, coupled with a Federal Market Order, which facilitates a marketing program based on quality and mild flavor (Boyhan and Torrance, 2002). Organic production, which has been around for over 30 years, has gained new impetus with the adoption of the U.S. Department of Agriculture (USDA) National Organic Program (NOP), which defines organic production for the purposes of marketing (USDA, 2003). Vidalia onion growers have become increasingly interested in the possibility of producing organic onions. This has been largely market driven, with their buyers requesting organic Vidalia onions. Coupled with this, the potential for more revenue per unit and a small, but growing industry in

${ }^{1}$ Associate Professor, Department of Horticulture, University of Georgia, East Georgia Extension Center, P.O. Box 8112, GSU, Statesboro, GA 30460

${ }^{2}$ Farm Superintendent, Vidalia Onion and Vegetable Research Center, 8163 Hwy 178, Lyons, GA 30436

${ }^{3}$ Corresponding author. E-mail: gboyhan@uga.edu. organic onion production has developed in the Vidalia region of southeastern Georgia.

Research has been conducted in many parts of the world on organic onion production. In a study of onions and rice (Oryza sativa), it was found that applications of farmyard manure, pelleted manure, neem (Azadirachta indica) seed powder, and karanj cake (Pongamia pinnata) with $75 \%$ of the recommended inorganic fertilizer $\left[100 \mathrm{~kg} \cdot \mathrm{ha}^{-1} \mathrm{~N}\right.$, $60 \mathrm{~kg} \cdot \mathrm{ha}^{-1}$ phosphorus (P), and $80 \mathrm{~kg} \cdot \mathrm{ha}^{-1}$ potassium $\left.(\mathrm{K})\right]$ resulted in increased onion bulb diameter and vitamin $\mathrm{C}$ content compared with using inorganic fertilizers alone (Mondal et al., 2004).

Farmyard manure, chicken manure, and inorganic fertilizers were compared for their effect on onion yield and onion characteristics (Khalil et al., 2002). This study found that chicken manure at $25 \mathrm{~m}^{3} /$ feddan (31.5 yard $^{3} /$ acre; Young and Glover, 1996) resulted in the highest average bulb weight and marketable bulb yield. Chicken manure and inorganic fertilizers were more effective than farmyard manure in improving growth. In another study of organic amendments in onion production, it was found that an integration of organic amendments (farmyard manure or vermicompost) and biofertilizers with inorganic fertilizers resulted in higher yields and greater growth than the inorganic fertilizer alone (Jayathilake et al., 2002). Because the amendments and biofertilizers were integrated with inorganic fertilizers, it is difficult to assess the importance of the organic components of the fertility program. Similarly, Selvakumari et al. (2001) found in a study of nutrient rates on various crops, including onions, that the inclusion of organic manures and biofertilizers reduced the required amounts of inorganic $\mathrm{N}, \mathrm{P}$, and $\mathrm{K}$.

Application timing has also been studied with overwintering crops, including onions. In a comparison of composted chicken manure, mature farmyard manure, ground bark and wood, and inorganic fertilizers in Slovenia, it was found that organic fertilizers applied during summer months supplied enough mineralized $\mathrm{N}$ for overwintering crops without the high leaching that occurs with inorganic fertilizers, even when those inorganic fertilizers are split-applied (Mihelic and Jakse, 2001).

Along with research on organic fertility programs for onions, various green manures have been studied as a $\mathrm{N}$ source for onion production. In a study in Denmark it was found that hairy vetch (Vicia villosa) resulted in the highest amount of mineral $\mathrm{N}$ (Willumsen and Thorup-Kristensen,

\begin{tabular}{llll}
\hline $\begin{array}{l}\text { Units } \\
\begin{array}{l}\text { To convert U.S. to SI, } \\
\text { multiply by }\end{array}\end{array}$ & U.S. unit & SI unit & $\begin{array}{l}\text { To convert SI to U.S., } \\
\text { multiply by }\end{array}$ \\
\hline 0.3048 & $\mathrm{ft}$ & $\mathrm{m}$ & 3.2808 \\
2.54 & inch $(\mathrm{es})$ & $\mathrm{cm}$ & 0.3937 \\
25.4 & inch $(\mathrm{es})$ & $\mathrm{mm}$ & 0.0394 \\
1.1209 & ib/acre & $\mathrm{kg} \cdot \mathrm{ha}^{-1}$ & 0.8922 \\
28.3495 & $\mathrm{oz}$ & $\mathrm{g}$ & 0.0353 \\
2.2417 & ton/acre & $\mathrm{t} \cdot \mathrm{ha}^{-1}$ & 0.4461 \\
1.8893 & yard $/ \mathrm{acre}$ & $\mathrm{m}^{3} \cdot \mathrm{ha}^{-1}$ & 0.5293
\end{tabular}


2001). In addition, green manures reduced $\mathrm{N}$ leaching by $50 \%$ to $85 \%$.

Fertilizer sources, whether inorganic or organic, were compared for their effect on onion thrip (Thrips tabaci) populations with no difference between treatments even when applied at rates three times the recommended rates (Gonçalves and Sousa e Silva, 2004). Weed control can be particularly problematic in organic production because the use of chemical herbicides is precluded. In one study that investigated the cost and impact of weeding strategies in onions, it was found that early weeding when the crop was young had the most impact on subsequent yield, whereas frequent weeding, particularly costly hand weeding, reduced economic returns, indicating the importance of timing of weed removal (Bourdôt et al., 2004). Boyhan et al. (2006) found that natural mulches such as wheat straw (Triticum aestivum), Bermuda grass hay (Cynodon dactylon), or pine needles (Pinus spp.) were not very effective at controlling weeds in organically produced onions compared with hand weeding. In a survey of organic versus conventional farms, it was found that the variety of weeds increased in organic systems, but the weed biomass was often the same or less (Ngouajio and McGiffen, 2002). It was postulated that soil microorganisms and phytophagous insects were reducing weed populations along with the physical and allelopathic effects of cover crops.

Onion varieties also have been investigated for production under organic conditions. Piazza et al. (2003) showed differences among the 12 varieties they tested.

Disease control is another area that has been investigated in organic onion production. In one study, various organic amendments were evaluated for their effect on onion bulb rot caused by Fusarium oxysporum f.sp. cepae and Aspergillus niger (Ozer et al., 2002). All amendments suppressed these pathogens primarily because of the increase in heterotrophic fungal populations. Amendments included sunflower stalks (Helianthus annuus), lucerne (Medicago sativa), and Hungarian vetch (Vicia pannonica).

Onion production in the Vidalia region is primarily a transplanted crop with transplants produced on-farm in high-density plantings (Boyhan et al., 2001). Transplant production has several advantages over direct seeding, such as reducing the potential for freeze injury with a uniform, appropriately spaced stand. Because transplant production is the dominant method of production, it has been adopted for organic onion production, but not without problems. Onion seedlings are difficult to produce in a timely manner because of their slow growth during fall production. In addition, they require relatively high $\mathrm{N}$ rates (130 lb/acre $\mathrm{N}$ ) during the short production time (8-10 weeks). This study was undertaken to evaluate fresh poultry litter, commercial organic fertilizer, and compost for their effect on onion transplant growth.

\section{Materials and methods}

POULTRY LITTER RATE EXPERIMENT. These experiments were conducted at the Vidalia Onion and Vegetable Research Center in Lyons, Georgia (lat. $32^{\circ} 11^{\prime} \mathrm{N}$, long. $82^{\circ} 17^{\prime} \mathrm{W}$ ) on a Tifton soil (fineloamy, siliceous, thermic Plinthic Paleudults). The research site was on NOP-certified (Georgia Crop Improvement Association, Athens, GA) land.

Plant beds were formed on 6 - $\mathrm{ft}$ centers with a bed width of $4 \mathrm{ft}$ and a height of 7 inches. In 2003 and 2004 , four rows were sown on these beds with a Monosem vacuum planter model 540 (ATI, Lenexa, KS) with a 190-hole plate set to sow double rows for each hopper with an in-row spacing of $3 / 8$ inches and a between-row spacing of 12 inches. This resulted in sowing 256 seeds per linear foot of bed with four double rows.

In 2003, untreated 'Granex EM90' seeds (Clifton Seed, Moultrie, GA) were sown on 17 Sept., and in 2004 a combination of equal parts of 'XON-202Y' (Sakata Seed, Morgan Hill, CA), 'HSX-18201 F ', 'HSX$19406 \mathrm{~F}_{1}$ ', and 'HSX-61304 $\mathrm{F}_{1}$ ' (Hortag Seed Co., Chapel Hill, NC) were sown on 1 Oct. All of these seeds were chosen because they were untreated and represent midseason onion varieties in the Vidalia-growing region of southeastern Georgia. In 2004, there were insufficient seeds of any one variety; therefore, a combination of varieties was used.
In a 2-year study (2003-04), poultry litter, obtained from a local source, was applied at rates of $0,2,4$, 6,8 , and 10 tons/acre (Table 1 ). In 2003 , one-half of the treatment rate was applied on 22 Sept. and one-half was applied on 23 Oct. on plots that were $20 \mathrm{ft}$. of seeded plant bed. Onion transplants were harvested on 3 Dec. 2003. In 2004, one-half of the treatment rate was applied on 1 Oct. and one-half was applied on 1 Nov. to $10-\mathrm{ft}$. plots. Onion transplants were harvested on 13 Dec. 2004. The experiments in both years were randomized complete block designs with four replications.

A random sample of five plants from each experimental unit was evaluated for length, which was measured from the basal plate to the tip of the longest leaf. In addition, transplant diameter was measured at the widest point across the bulb area, $\approx 1 \mathrm{~cm}$ above the basal plate. Finally, the fresh weight of a random sample of 20 plants was obtained from each experimental unit.

ORgANIC FERTILIZER AND COMPOST EXPERIMENT. In 2004, an additional experiment was performed evaluating compost and organic fertilizer in a factorial arrangement of a randomized complete block design with four replications. Organic fertilizer $\quad(4 \mathrm{~N}-0.9 \mathrm{P}-2.5 \mathrm{~K}$; Perdue AgriRecycle, Horsham, PA) was applied at two rates $(0$ or $130 \mathrm{lb} /$ acre $\mathrm{N}$ ) in combination with three rates of compost $(0,5$, or 10 tons/acre $)$.

The experimental unit consisted of $10 \mathrm{ft}$. of seeded bed using the variety seed mix as described previously. The compost was preplant incorporated at the treatment rates. The compost was a locally produced material (Longwood Plantation, Newington, GA) made from cotton gin trash and peanut hulls (Arachis

Table 1. Nutrient content of poultry litter used for onion transplant production. ${ }^{\mathrm{z}}$

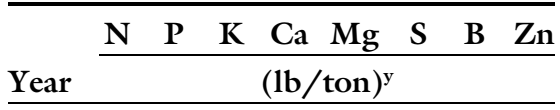

$\begin{array}{lllllllll}2003 & 66 & 39 & 63 & 53 & 13 & 10 & <1 & <1\end{array}$ $\begin{array}{lllllllll}2004 & 62 & 51 & 41 & 75 & 21 & 8 & <1 & <1\end{array}$

${ }^{\mathrm{z}} \mathrm{N}=$ nitrogen, $\mathrm{P}=$ phosphorus, $\mathrm{K}=$ potassium, $\mathrm{Ca}=$ calcium, $\mathrm{Mg}$ = magnesium, $\mathrm{S}=$ sulfur, $\mathrm{B}$ = boron, $\mathrm{Zn}=$ zinc. Analyzed by Agricultural and Environmental Services Laboratories, University of Georgia, Athens. ${ }^{\mathrm{y}} \mathrm{l} \mathrm{lb} / \mathrm{ton}=2.0 \mathrm{~kg} \cdot \mathrm{ha}^{-1}$. 
bypogaea) in a windrow system that met the NOP guidelines for compost (USDA, 2003). The $4 \mathrm{~N}-0.9 \mathrm{P}-2.5 \mathrm{~K}$ fertilizer was manufactured from poultry litter and was split-applied with one-half applied preplant and incorporated just before sowing on 1 Oct. 2004. The second half of the fertilizer was applied l Nov. 2004. Plants were harvested on 13 Dec. 2004 , and length, diameter, and plant weights were measured as described previously.

\section{Results and discussion}

The nutrient content of poultry litter is shown in Table 1. These values are higher than the averages reported for Georgia for primary and secondary nutrients (Kissel, 2003), but are in line with other reported values such as from Virginia Polytechnic Institute (Mullins et al., 2002).

There were significant differences in transplant weight based on the amount of poultry litter applied (Table 2). In addition, there was a significant linear increase in plant weight. Results were similar for plant length with a significant increasing quadratic effect. There was a linear increase in plant diameter with increasing poultry litter. There was no treatment by year interaction effect, indicating that using different varieties each year had no effect on the treatments.

In the factorial experiment examining compost and organic fertilizer, there was a significant fertilizer effect on plant length (Table 3 ). Compost, however, did not affect plant length. There was a significant compost-by-fertilizer interaction for plant diameter. An examination of the interaction indicated a significant effect of fertilizer when compost was applied at 10 tons/acre. Plant weight also reflected a significant compostby-fertilizer interaction with a significant fertilizer effect at 5 and 10 tons/ acre compost application rates.

Plant length and diameter were not as important as plant weight in assessing treatment effects. When transplants are harvested, $\approx \mathbf{5 0} \%$ of the tops are removed before transplanting. Removal of this plant tissue makes the transplants easier to handle, reduces transpiration stress, reduces subsequent spring flowering, and insures a stand of uniform plants. Because this tissue is routinely removed, plant length is probably not a good indicator of plant vigor and survivability.

Plant diameter is also a difficult parameter to use to determine transplant quality. Although we recommend a transplant be the diameter of a pencil or greater $(\geq 8.0 \mathrm{~mm})$, most of these treatments met this minimum, making it difficult to determine optimum fertility. Short-day onions require a shorter daylength to begin bulbing, but they do require a minimum of 11 to $12 \mathrm{~h}$ of daylight, and because transplants are grown in the fall when days are getting shorter, there is not an appreciable increase

Table 2. Effect of poultry litter rates on growth of onion transplants in 2003-04.

\begin{tabular}{|c|c|c|c|}
\hline $\begin{array}{l}\text { Poultry litter } \\
\text { treatment (tons/acre) }\end{array}$ & $\begin{array}{c}\text { Plant wt } \\
(\mathrm{g} \text { per } 20 \text { plants })^{\mathrm{z}, \mathrm{y}}\end{array}$ & $\begin{array}{c}\text { Plant length } \\
{\text { (inches) })^{, y}}^{-1}\end{array}$ & $\begin{array}{c}\text { Plant } \\
\operatorname{diam}(\mathrm{mm})^{\mathrm{z}, \mathrm{x}} \\
\end{array}$ \\
\hline 0 & 73.7 & 9.4 & 7.7 \\
\hline 2 & 85.1 & 12.1 & 7.8 \\
\hline 4 & 113.5 & 13.2 & 8.9 \\
\hline 6 & 140.1 & 14.7 & 9.1 \\
\hline 8 & 146.3 & 14.9 & 9.8 \\
\hline 10 & 166.3 & 16.1 & 10.7 \\
\hline $\mathrm{CV}^{\mathrm{w}}$ & $21 \%$ & $31 \%$ & $38 \%$ \\
\hline Fisher's protected LSD ${ }^{\mathrm{w}}(P=0.05)$ & 36.3 & 2.4 & 2.2 \\
\hline \multicolumn{4}{|l|}{ Probabilities } \\
\hline Treatment & 0.004 & 0.000 & 0.000 \\
\hline Year & 0.006 & 0.000 & 0.000 \\
\hline Treatment $\times$ year & 0.822 & 0.456 & 0.353 \\
\hline Linear & 0.003 & 0.000 & 0.000 \\
\hline Quadratic & 0.829 & 0.024 & 0.493 \\
\hline
\end{tabular}

${ }^{\mathrm{z}} \mathrm{l}$ ton $/$ acre $=2.2417 \mathrm{t} \cdot \mathrm{ha}^{-1}, \mathrm{l} \mathrm{g}=0.0353 \mathrm{oz}, \mathrm{l}$ inch $=2.54 \mathrm{~cm}, \mathrm{l} \mathrm{mm}=0.0394$ inch.

${ }^{y}$ Measurements were made on intact plants with roots removed.

${ }^{x}$ Measured $\approx 1 \mathrm{~cm}(0.4$ inch $)$ above the basal plate at the widest part of the plant.

${ }^{\mathrm{w}_{\mathrm{CV}}}=$ coefficent of variation, $\mathrm{LSD}=$ least significant difference. in bulb size at this time even though the plants are growing.

Plant weight was the most appropriate measure in assessing transplants. Even though $50 \%$ of the tops are removed in commercial production, the overall weight (weights in this study are of entire plants) still reflects the mass and therefore the suitability for transplanting. Although no direct comparison with conventionally produced transplants was possible, we did measure several bundles of 20 plants of conventionally produced onions and they averaged between 130 and 150 g per 20 plants. In the poultry litter rate study, treatments of 6 tons/acre or greater produced plant weights that were within or greater than this range (Table 2).

Based on the analyses of the poultry litter, the amount of $\mathrm{N}$ applied ranged from 0 to over 600 $\mathrm{lb} / \mathrm{acre}$, with the best transplants produced with 6 ton/acre or more of poultry litter. This reflects a $\mathrm{N}$ application rate of $360 \mathrm{lb} /$ acre or greater. It should be noted, however, that much of the $\mathrm{N}$ is not in a plantavailable form, nitrate $\left(\mathrm{NO}_{3}^{-}\right)$or ammonium $\left(\mathrm{NH}_{4}^{+}\right)$. Whitmore (2007) indicated that only $40 \%$ of $\mathrm{N}$ in applied poultry litter is available for crops the first year. This brings the available $\mathrm{N}$ more in line with our recommendations for conventionally produced onions. Although poultry litter has been shown to be a suitable source of fertilizer in this study and others, caution is recommended with its use. High rates of application over several years can result in excessive nutrient buildup (Kissel, 2003). This can easily happen because of the fraction of nutrients that are unavailable at the time of application.

In the second study, organic fertilizer applied at $130 \mathrm{lb} /$ acre in combination with the high compost rate ( 10 tons/acre) was the only treatment that produced plant weights that exceeded conventionally produced transplants (Table 3). This points out the apparent synergistic effect of using compost in conjunction with the organic fertilizer. Our experience with organic fertilizers is that they do not perform like a conventional fertilizer with the same analysis. This makes sense because organic fertilizer has to undergo a mineralization process before the 
Table 3. Evaluation of compost and organic fertilizer on growth of onion transplants.

\begin{tabular}{|c|c|c|c|c|c|c|}
\hline \multirow[b]{3}{*}{ Compost (tons/acre) ${ }^{\mathrm{y}}$} & \multicolumn{2}{|c|}{$\begin{array}{c}\text { Plant wt } \\
(\text { g per } 20 \text { plants })^{\mathrm{z}, \mathrm{y}}\end{array}$} & \multicolumn{2}{|c|}{$\begin{array}{l}\text { Plant length } \\
\text { (inches) }^{z, y}\end{array}$} & \multicolumn{2}{|c|}{$\begin{array}{c}\text { Plant } \\
\operatorname{diam}(\mathrm{mm})^{\mathrm{y}, \mathrm{x}}\end{array}$} \\
\hline & \multicolumn{6}{|c|}{ Nitrogen $(1 \mathrm{~b} / \text { acre from } 4 \mathrm{~N}-0.9 \mathrm{P}-2.5 \mathrm{~K}-3 \mathrm{Ca})^{\mathrm{y}}$} \\
\hline & $\mathbf{0}$ & 130 & $\mathbf{0}$ & 130 & $\mathbf{0}$ & 130 \\
\hline 0 & 112.8 & 109.2 & 10.8 & 12.8 & 9.5 & 10.1 \\
\hline 5 & 58.2 & 118.8 & 9.9 & 13.6 & 8.9 & 9.9 \\
\hline 10 & 90.2 & 173.3 & 11.6 & 16.2 & 8.6 & 11.2 \\
\hline \multicolumn{7}{|l|}{ Probabilities } \\
\hline Compost & \multicolumn{2}{|c|}{0.054} & \multicolumn{2}{|c|}{0.389} & \multicolumn{2}{|c|}{0.797} \\
\hline Fertilizer & \multicolumn{2}{|c|}{0.003} & \multicolumn{2}{|c|}{0.023} & \multicolumn{2}{|c|}{0.062} \\
\hline Compost X Fertilizer & \multicolumn{2}{|c|}{0.046} & \multirow{2}{*}{\multicolumn{2}{|c|}{0.181}} & \multicolumn{2}{|c|}{0.013} \\
\hline \multicolumn{5}{|l|}{ Compost with } & & \\
\hline $0 \mathrm{lb} /$ acre $\mathrm{N}$ & \multicolumn{2}{|c|}{0.143} & & & \multicolumn{2}{|c|}{0.549} \\
\hline $130 \mathrm{lb} /$ acre $\mathrm{N}$ & \multicolumn{2}{|c|}{0.098} & & & \multicolumn{2}{|c|}{0.445} \\
\hline \multicolumn{7}{|l|}{ Fertilizer with } \\
\hline 0 tons/acre compost & \multicolumn{2}{|c|}{0.843} & & & \multicolumn{2}{|c|}{0.159} \\
\hline 5 tons/acre compost & \multicolumn{2}{|c|}{0.020} & & & \multicolumn{2}{|c|}{0.092} \\
\hline 10 tons/acre compost & \multicolumn{2}{|c|}{0.006} & & & \multicolumn{2}{|c|}{0.047} \\
\hline
\end{tabular}

${ }^{\mathrm{z}}$ Measurements were made on intact plants with roots removed.

${ }^{\mathrm{y}} \mathrm{l} \mathrm{g}=0.0353 \mathrm{oz}, \mathrm{l}$ inch $=2.54 \mathrm{~cm}, 1 \mathrm{~mm}=0.0394 \mathrm{inch}, \mathrm{l} \mathrm{lb} / \mathrm{acre}=1.1209 \mathrm{~kg} \cdot \mathrm{ha}^{-1}, \mathrm{l} \mathrm{ton} / \mathrm{acre}=2.2417 \mathrm{t} \cdot \mathrm{ha}^{-1}$ ${ }^{x}$ Measured $\approx 1 \mathrm{~cm}(0.4 \mathrm{inch})$ above the basal plate at the widest part of the plant.

nutrients are in a plant-available form. This is particularly true for $\mathrm{N}$.

Results from this study are mirrored in other studies. Various researchers have found that including organic components such as farmyard manure and compost improved plant growth performance compared with using fertilizers alone (Jayathilake et al., 2002; Khalil et al., 2002; Selvakumari et al., 2001). We see this with the interaction effect of compost and organic fertilizer on plant weight. In addition, incorporating organic material alone such as compost does not result in adequate growth; fertilizers, whether organic or conventional, must supply adequate levels of plant available nutrients, particularly N. Khalil et al. (2002) found similar results where farmyard manure alone was not as effective as inorganic fertilizers or chicken manure, which would have appreciably higher levels of plant-available N.

There are advantages and disadvantages to using poultry litter versus using organic fertilizer/compost combination for transplant production. Poultry litter is readily available and inexpensive in southeastern Georgia where poultry production is a large industry. Poultry litter can, however, be quite variable from one source to another and should be analyzed before application so that adjustments in rate can be made.
Poultry litter may also be a source of various heavy metals and may contribute to environmental degradation due to runoff and leaching with repeated application. Organic fertilizer and compost can be used up to time of harvest, giving growers greater flexibility in use under the NOP rules that require $120 \mathrm{~d}$ before harvest when using fresh manures. This, however, is not a problem in onion transplant production because there is sufficient time from application to harvesting bulbs. Organic fertilizers, although they list the $\mathrm{N}, \mathrm{P}$, and $\mathrm{K}$ available, are difficult to use because they do not respond like an inorganic fertilizer. Because the nutrient sources are organic, mineralization is required before nutrients are available and this can be difficult to predict because of variable environmental conditions. Finally, good quality compost can be applied repeatedly without concern for environmental degradation. In fact, repeated application can make for large improvements in soil condition with better water and nutrient-holding capacity and general soil fertility. Quality compost, however, can be expensive, particularly when applied at high rates.

Further work, particularly on the mineralization rates and application timing with organic fertilizers, needs to be accomplished in southeastern
Georgia. Predicting nutrient availability under varying environmental and soil conditions would be helpful to extension personnel and ultimately to organic growers.

In conclusion, supplying adequate nutrients to produce onion transplants can be done in an organic system. The Vidalia-growing region of southeastern Georgia has abundant supplies of poultry litter because Georgia is a major poultry producer. Commercial organic fertilizer that meets NOP standards is also available and, more importantly, it is available in commercial quantities with affordable prices within the organic market structure.

\section{Literature cited}

Boatright, S.R. and J.C. McKissick. 2006. 2005 Georgia farm gate value report. Univ. of Georgia Coop. Ext. Serv. Area Rpt. AR-06-01.

Bourdôt, G.W., G.A. Hurrell, and D.J. Saville. 2004. Estimating when to weed an organically grown onion crop. 14th Australian Weeds Conf., Weed management: Balancing people, planet, profit, Wagga Wagga, New South Wales, Australia, 6-9 Sept. 2004. p. 182-186.

Boyhan, G.E., D.M. Granberry, and W.T. Kelley. 2001. Onion production guide. Univ. of Georgia Bull. No. 1198.

Boyhan, G.E., R. Hicks, and C.R. Hill. 2006. Natural mulches are not very effective for weed control in onions. HortTechnology 16:523-526.

Boyhan, G.E. and R.L. Torrance. 2002. Vidalia onions: Sweet onion production in southeastern Georgia. HortTechnology 12:196-202.

Gonçalves, P.A.d.S. and C.R. Sousa e Silva. 2004. Mineral and organic fertilization and onion thrips, Thrips tabaci Lind. (Thysanoptera: Thripidae) population density. Ciência Rural 34:12551257.

Jayathilake, P.K.S., I.P. Reddy, D. Srihari, G. Neeraja, and R. Ravinder. 2002. Effect of nutrient management on growth, yield and yield attributes of rabi onion (Allium cepa L.). Veg. Sci. 29:184-185.

Khalil, F.A., A.S.A. El-Hamd, E.I. Mohamed, and M.A.M. Hassan. 2002. Response of onion crop var. Shandaweel 1 to some sources of organic fertilizers. Assiut J. Agr. Sci. 33:73-83.

Kissel, D. 2003. Soil test handbook for Georgia. Univ. of Georgia, Athens. 
Mihelic, R. and M. Jakse. 2001. Nitrogen dynamics in intensive vegetable crop rotation influenced by organic fertilisation. Acta Hort. 563:163-170.

Mondal, S.S., A. Debabrata, G. Arup, and U. Thapa. 2004. Integrated management of organic and inorganic sources of nutrient to improve productivity and qualitative characters of rice and onion in rice-onion cropping sequence. Environ. Ecol. 22:125-128.

Mullins, G.L., E.S. Bendfeldt, and R.A. Clark. 2002. Poultry litter as a fertilizer and soil amendment. 13 June 2007. <http://www.ext.vt.edu/pubs/ poultry/424-034/424-034.html>.

Ngouajio, M. and M.E. McGiffen, Jr. 2002. Going organic changes weed population dynamics. Hort Technology 12:590-596.

Ozer, N., N.D. Koycu, M. Mirik, H. Soran, and D. Boyraz. 2002. Effect of some organic amendments on onion bulb rot. Phytoparasitica 30:429-433.

Piazza, C., R. Reggiani, and M.C. Cera. 2003. Varietal experiments on organically grown onions. Sementi Elette 49:39-41.

Selvakumari, G., R. Santhi, R. Natesan, and K. Sathiyabama. 2001. Soil test and vegetable crop response under integrated plant nutrition system for optimization of fertilizer doses. South Indian Hort. 49:130-136.

U.S. Department of Agriculture. 2003. National Organic Program home. 12 Oct.
2003. <http://www.ams.usda.gov/ nop/indexIE.htm $>$.

Whitmore, A.P. 2007. Determination of the mineralization of nitrogen from composted chicken manure as affected by temperature. Nutrient Cycling Agroecosystems 77:225-232.

Willumsen, J. and K. Thorup-Kristensen. 2001. Effects of green manure crops on soil mineral nitrogen available for organic production of onion and white cabbage in two contrasting years. Biol. Agr. Hort. 18:365-384.

Young, R.A. and T.J. Glover. 1996. Measure for measure. Blue Willow, Littleton, CO. 